\title{
Wood anatomy of Salix $\times$ rubens Schrank used for basketry in Brazil
}

\author{
Mariana de Andrade Wagner ${ }^{1,2}$, Maria Cecília de Chiara Moço ${ }^{1}$, Alison Tadeu Sawczuk ${ }^{1}$ e Patricia Soffiatti ${ }^{1}$
}

Received: 14.04.2008; accepted: 27.11.2008

ABSTRACT - (Wood anatomy of Salix $\times$ rubens Schrank used for basketry in Brazil). In Southern Brazil, in the Plateau of the State of Santa Catarina, species of Salix (willow), vernacularly called "vime", are cultivated for weaving crafts. The hybrid Salix $\times$ rubens Schrank (Salicaeae) is the widely cultivated species in the region. The research institute "Empresa de Pesquisa Agropecuária e Extensão Rural de Santa Catarina (EPAGRI)" in the city of Lages, is developing a program to improve the quality of the willow for basketry. Wood samples of young rods and the main trunk of Salix $\times$ rubens were collected, fixed and sectioned according to usual techniques in wood anatomy. Qualitative and quantitative features were described, following the IAWA Committee recommendations. Wood anatomy is characterized by solitary vessels, with simple perforation plate, alternate bordered intervessel pits, vessel-ray pits similar to intervessel pits, axial parenchyma scanty apotracheal to diffuse, septate and non-septate fibres, with simple to minutely bordered pits, uniseriate rays. Wood of young and mature samples are very similar, differing only in the presence of growth rings in the latter. This work characterizes the wood anatomy of young and adult samples of Salix $\times$ rubens, not described so far, aiming to improve the knowledge about the species.

Key words: Salicaceae, willow, wood anatomy

RESUMO - (Anatomia da madeira de Salix $\times$ rubens Schrank usado para cestaria no Brasil). Na Região Sul do Brasil, no Planalto Serrano Catarinense, plantas do gênero Salix, chamadas popularmente de vime, são cultivadas para o artesanato de trançado. A mais comum na região é o híbrido Salix $\times$ rubens Schrank (Salicaceae). A Empresa de Pesquisa Agropecuária e Extensão Rural de Santa Catarina (EPAGRI) no município de Lages desenvolve um programa para o melhoramento da qualidade do vime da região. Amostras de ramos e do caule adulto de Salix $\times$ rubens foram coletadas, fixadas e seccionadas de acordo com técnicas usuais em anatomia da madeira, para descrição qualitativa e quantitativa do lenho, seguindo o IAWA Committee. A anatomia da madeira da espécie é caracterizada por vasos solitários, com placa de pefuração simples, pontoações intervasculares areoladas alternas, similares às raio-vasculares, parênquima axial apotraqueal difuso a escasso, fibras septadas e não septadas, com pontoações diminutas, areoladas a simples, raios unisseriados. A anatomia da madeira das amostras dos ramos e do caule adulto é bem parecida, diferindo somente na presença de camadas de crescimento nas amostras adultas. Nesse trabalho foi caracterizada a anatomia da madeira de ramos e caule adulto de Salix $\times$ rubens Schrank, ainda não descrita, visando contribuir para o melhor conhecimento da espécie.

Palavras-chave: Anatomia do xilema secundário, Salicaceae, vime

\section{Introduction}

The genus Salix (Salicaceae) comprises 400 species and 200 hybrids, occuring in all continents, being most numerous in the Northern Hemisphere (Newsholme 2002). One of the factors responsible for the cosmopolitan distribution of Salix today is the interchange of species and hybrids between America, Europe and Asia over many centuries for the manufacturing of objects by weaving together the long and thin willow wands.

Vernacularly known as willow, it has many uses all around the world. In England, the species used for basketry are Salix triadra L., S. purpurea L., and S. viminalis L. (Newsholme 2002); in North America weavers prefer native species like $S$. scouleriana Barr., S. eriocephala Michx., and the clone $S$. "Americana", resulting from hybridization between $S$. eriocephala Michx. and S. petiolaris Sm. (S. gracilis Anderss.); European settlers introduced S. purpurea L., S. pentandra L. and S. viminalis L. in Western United States (Dorn 1976, Newsholme 2002); in Japan, the local species $S$. kinuyanagi Kimura, which is similar to $S$. viminalis $\mathrm{L}$., is used for coarser basketry, while the Korean native species $S$. koriyanagi Kim., closer to $S$. purpurea L., is used for basketry of better quality (Kimura 1965, Newsholme

1. Universidade Federal do Paraná, Setor de Ciências Biológicas, Departamento de Botânica, Centro Politécnico, Caixa Postal 19031, 81531900 Curitiba, PR, Brasil

2. Autor para correspondência: patricia.soffiatti@ufpr.br 
2002); in South America, the species Salix viminalis L. is used in Chile and Salix $\times$ rubens Schrank, a hybrid between Salix alba L. and Salix fragilis L., is used in Brazil (Moura 2002, Corrêa 1984).

In the South-Brazilian state of Santa Catarina, in small towns around the city of Lages (such as Rio Rufino, Bom Retiro, Bocaina do Sul, Urubici, Urupema and Palmeira), farmers cultivate willows for basketry, where Salix $\times$ rubens Schrank is the most cultivated species. Italian immigrants introduced Salix to tie their vines with its long wands. The plants became naturalized and spread throughout the states of São Paulo, Paraná, Santa Catarina, and Rio Grande do Sul. Nowadays, this hybrid occurs spontaneously along water bodies. In the last ten years the willow cultivation has become an alternative economic activity for some farmers of the region (Moura 2002, Tagliari 1998).

The local agency for rural development ("Empresa de Pesquisa Agropecuária e Extensão Rural de Santa Catarina - EPAGRI") has a program for sustainable development of the willow cultivation for basketry in the Santa Catarina Plateau, which one of its objectives is to improve their genetic base. The agency introduced news species that can adapt to the climate and soil conditions of the area. EPAGRI together with the Brazilian agency EMBRAPA (CENARGEM) imported 19 Salix species and varieties from Germany, as well as Salix viminalis from Portugal (Moura 2002).

The quality of the willow wands from Santa Catarina for basketry manufacture depends on many factors: genetic quality of the material, cultivation methods, and processing methods. The hybrid Salix $\times$ rubens presents a great amount of pith and low production of wood, which affects flexibility, elasticity and twisting capacity, essential characteristics to the manufacture of willow basketry (Moura 2002).

There is neither any work relating wood characteristics of the genus Salix with its use in the weaving of baskets, nor any about the structure of the Brazilian Salix secondary xylem. Some recent scientific works relate characteristics of the secondary xylem of Salix species to environmental conditions and pollution in Canada and Eastern Europe (Cooper \& Cass 2001, Chavchavadze et al. 2002, Sizonenko \& Chavchavadze 2002). Other works relate wood properties of Salix to the production of furniture (Bloskova et al. 1983, Blossfeld et al. 1990, Leclercq 1997).

So far there is only one work discussing basketry and wood anatomy, in some Bignoniaceae used for the weaving of baskets called "canastos" in Costa Rica, which has in its stem's anatomy some properties that justify compatibility for basket weaving (Benzecry 2005).

This work characterizes the wood anatomy of young and adult samples of Salix $\times$ rubens, not described so far, aiming to improve the knowledge about the most used species for basketry in South Brazil.

\section{Material and methods}

Sample rods of Salix $\times$ rubens were collected from 20 individuals, at the base of one year old twigs (young samples), at the EPAGRI property in Lages (9-II-2004, M. Wagner 1 UPCB 61306). In December 2006 EPAGRI supplied five mature samples of ten years old Salix $\times$ rubens trees, collected at breast height from the main trunk (1X-2007, M. Wagner 2-6). Voucher is deposited in the Herbarium (UPCB) at the Federal University of Paraná (UFPR). Samples of basal portions of the stems were fixed in $70 \%$ formalin-aceticalcohol (Johansen 1940). Samples of young rods were embedded with polyethylenglycol (PEG 1500) according to (Richter 1985) and sectioned in rotative microtome. Samples of the main trunk were sectioned in a sliding microtome, according to usual wood anatomy techniques (Gerlach 1984). Thick transverse and longitudinal sections (15-20 $\mathrm{mm}$ ) were double-stained with astrablue \& safranin and mounted in Permount ${ }^{\circledR}$. Macerations were prepared according to the modified Franklin Method (Franklin 1945), stained with safranin, and mounted in Permount ${ }^{\circledR}$. Terminology for descriptions followed the recommendations of the IAWA List of Microscopic Features for Harwood Identification (IAWA Committee 1989). The following parameters were measured: vessel diameter, vessel frequency, vessel element length and fibre length. Quantitative data were based on 25 measurements. Anatomical descriptions and measurements were taken under a light microscope Olympus CBB. Measurements were taken with the aid of a micrometer ruler connected to the objective lens, and analyzed and photographed using light microscope Zeiss Axiolab with photographic camera attached.

\section{Results and Discussion}

Wood structure of young and mature samples are similar, except for the presence of growth rings: one year old specimens are diffuse porous (figure 1) while adult specimens are semi-ring-porous (figure 2), marked by 
one layer of thick-walled radially flattened fibers (figure 3). Vessels are exclusively solitary (figures 1,2); $121(100-180) \mathrm{mm}^{2}$ in young rods and $76(40-114) \mathrm{mm}^{2}$ in adult; vessel diameter is $56(50-100) \mu \mathrm{m}$ in young rods and 66 (70-96) $\mu \mathrm{m}$ in adult; vessel element length is 446 $(350-800) \mu \mathrm{m}$ in young rods and $430(350-800) \mu \mathrm{m}$ in adults; perforation plates are simple (figure 4); bordered intervessel pits are alternate, polygonal (figure 5). Bordered vessel-ray pits are similar to intervessel pits. Axial parenchyma is scanty apotracheal to diffuse. Septate fibers and non-septate fibers are present, with simple to minutely bordered pits. Rays are exclusively uniseriate (figure 6), composed of procumbent square and upright cells (figure 7). Mean and standard deviation, and minimum and maximum values (between brackets) for each parameter are given in table 1.

The wood anatomy of the genus is quite uniform, and the general structure was already described for the genus Salix by Record \& Hess (1943). However the wood anatomy of Salix $\times$ rubens has not yet been described. For the species that yield this hybrid, Salix fragilis and Salix alba, Schoch et al. (2004) characterized their anatomy as well as of other Salix species from Central Europe, demonstrating their homogeneity. Détienne \& Jacquet (1983) describing the wood anatomy of Salix humboldtiana Wild, the native Salix species from South America, noticed some differences regarding porosity: this species differs from other Salix species in its diffuse-porous wood, while other Salix species, including the hybrid Salix $\times$ rubens, are semi-ring-porous. Metcalfe (1939) characterized the wood anatomy of the cricket-bat willow Salix caerulea Sm., considering it diffuseporous, but stating that: "the number of vessels per unit area is slightly greater in the outer part of the ring than in the early wood but the vessels are larger in the early wood and may occupy a greater total area". This could also be interpreted as semi-ring-porous, taking into account his afirmation of early wood vessels being larger and in greater number. Also, Metcafe (1939) describes vessel arrangement lacking any definite pattern, similarly to the hybrid Salix $\times$ rubens.

One of the few treatments of wood anatomy related to ecology of Salix is of Baas et al. (1983), in which the authors surveyed wood characteristics of two hydrophilic Salix species for ecological trends regarding vessel characters. Wider vesel elements are more efficient in water flow, yet present higher susceptibility to embolism (Baas et al. 1983). The Brazilian hybrid Salix $\times$ rubens occurs at river-banks and is subject to short periods of flooding. Therefore it can be considered an emergent hydrophilic species. Its vessel elements are longer and wider compared with those of mesic Salix species from the Athabasca sand dunes in Canada and with its widespread xeric putative sister species (Cooper $\&$ Cass 2001). Usually species which occur in xeric habitats present thinner and shorter vessel elements in a higher density than plants of mesic habitats (Baas et al. 1983, Carlquist 2001).
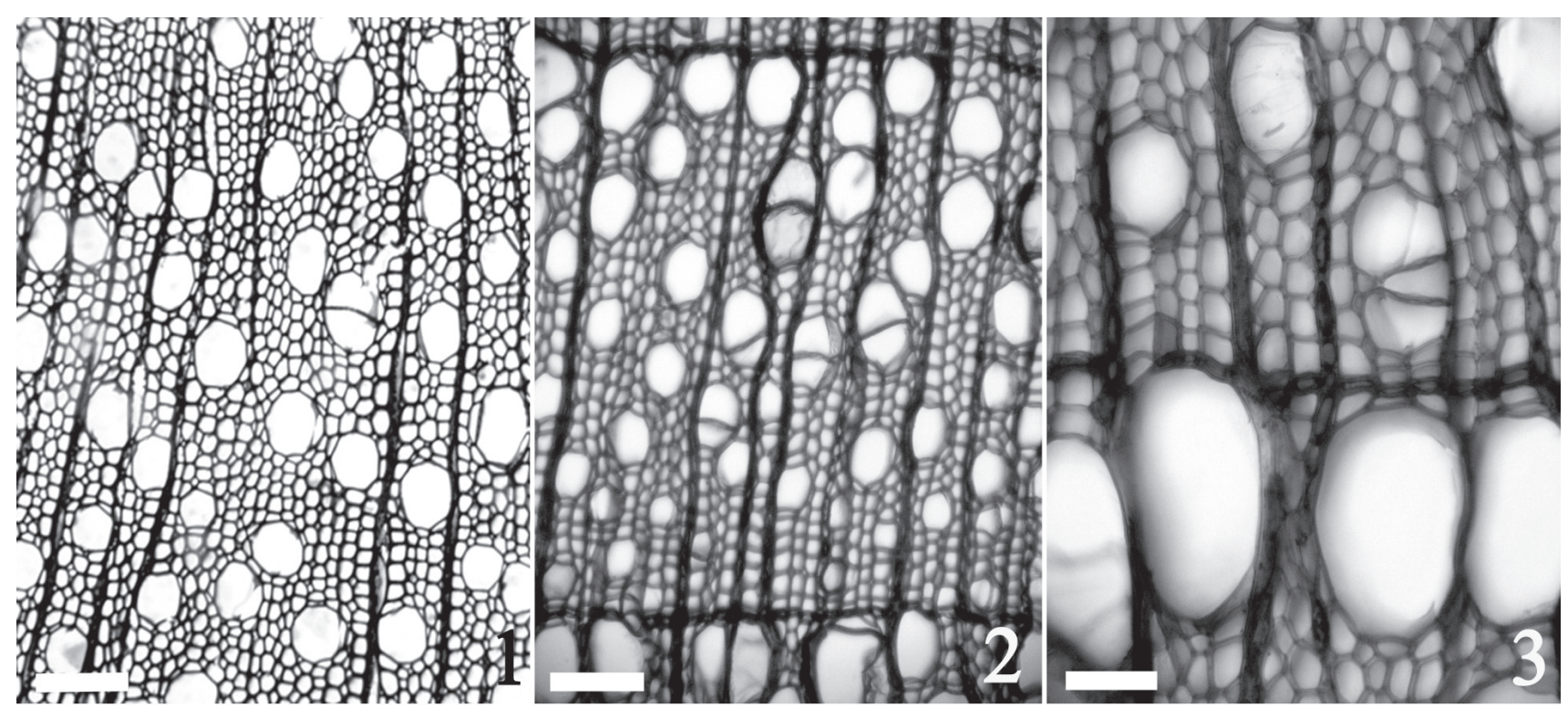

Figures 1-3. Salix $\times$ rubens Schrank. 1-3. Cross sections. 1. Wood of young rod. 2. Semi-ring porous adult stem wood. 3. High magnification of growth rings marked by thick walled and radially flattened fibres. Scale bars: $1-2=100 \mu \mathrm{m} ; 3=50 \mu \mathrm{m}$. 

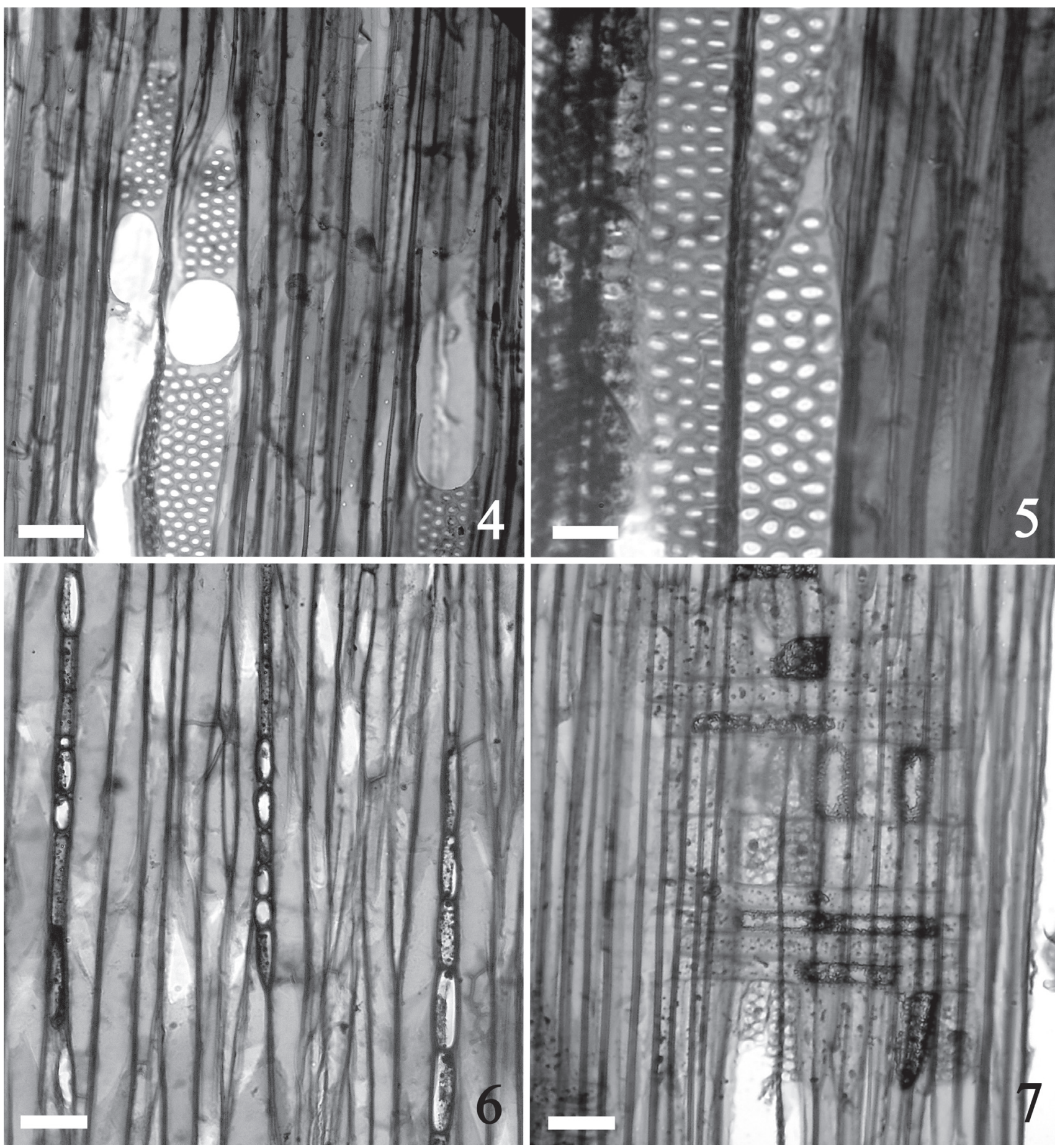

Figures 4-6. Salix $\times$ rubens Schrank. Tangential sections. 4. Simple perforation plate. 5. Alternate intervessel pits. 6. Uniseriate rays. 7. Radial section. Heterogeneous rays: procumbent cells and rows of upright and square cells. Scale bars: 4-5=30 $\mu \mathrm{m} ; 6-7=50 \mu \mathrm{m}$. 
Table 1. Mean values, standard deviation and minimum and maximum (between brackets) of wood anatomical features analyzed for young rods and adult stem of Salix $\times$ rubens Schrank $(\mathrm{n}=25)$.

\begin{tabular}{ccc}
\hline Wood anatomy features & Young rods & Adult stem \\
\hline Vessel diameter $(\mu \mathrm{m})$ & $56 \pm 8,85(31-92)$ & $66 \pm 18,33(37-113)$ \\
Vessel element length $(\mu \mathrm{m})$ & $446 \pm 51,66(374-876)$ & $430 \pm 70,96(348-811)$ \\
Vessel frequency $\left(\mathrm{n} . \mathrm{mm}^{-2}\right)$ & $121 \pm 1,67(96-135)$ & $76 \pm 13,41(53-98)$ \\
Fibres length $(\mu \mathrm{m})$ & $711 \pm 149,99(650-987)$ & $799 \pm 163,44(627-1134)$ \\
\hline
\end{tabular}

The wood anatomy of Salix $\times$ rubens is here first described, corroborating the general structure found for the genus Salix as a whole. There are no qualitative differences between young and adult wood, except for the presence of growth rings in the former, altough some quantitative features show differences.

\section{Acknowledgements}

This work was the first author Graduation Monography as a requirement for the conclusion of the Graduation Course in Biological Sciences of the Universidade Federal do Paraná (UFPR). We thank to two anonymous reviewers for providing helpful suggestions on the manuscript.

\section{Literature cited}

Baas, P., Fahn, A. \& Werker, E. 1983. Some ecological trends in vessel characters. IAWA Bulletin 4: 141-159.

Benzecry, A. 2005. "Canastos": ethnobotany and the economic importance. Economic Botany 59: 290-294.

Bloskova, G., Nikolov, S., Tsanov, T.I. \& Dragozov, I. 1983. Anatomical structure of the wood of some Salix alba clones. Gorskostopanska-Nauka 20: 29-36.

Blossfeld, O., Plotz, J. \& Blechschmidt, J. 1990. Wood properties of three willows. Wissenschaftliche Zeitschrift der Technischen Universität Dresden 39: 155-157.

Carlquist, S. 2001. Comparative wood anatomy. SpringerVerlag, New York.

Chavchavadze, E.S., Umarov, M.U. \& Volkova, S.B. 2002. Effect of industrial pollution of atmosphere on the structure of wood of Salix caprea L. and Betula tortuosa. Rastitel'nye Resursy 38: 104-111.

Cooper, R.L. \& Cass, D.D. 2001 . Comparative evaluation of vessel elements in Salix spp. (Salicaceae) endemic to the Athabasca sand dunes of northern Saskatchewan. American Journal of Botany 88: 583-587.

Corrêa, M.P. 1984. Dicionário das plantas úteis do Brasil e exóticas cultivadas. v. 6. Instituto Brasileiro de Desenvolvimento Florestal, Ministério da Agricultura, Brasilia.
Détienne, P. \& Jacquet, P. 1983. Atlas d'identification des bois de l'Amazonie et des régions voisines. Centre Téchnique Forestier Tropical, Norgent-sur-Marne.

Dorn, R.E. 1976. A synopsis of American Salix. Canadian Journal of Botany 54: 2769-2789.

Franklin, G. 1945. Preparations of thin sections of synthetic resins and wood - resin composites and a new macerating method for wood. Nature 155: 51.

IAWA Commitee. 1989. IAWA list of microscopic features for hardwood identification. IAWA Bulletin n.s. 10: 219-332.

Gerlach, D. 1984. Botanische Mikrotechnik. Sttutgart, Georg Thieme Verlag. Sttutgart.

Kimura, A. 1965. 'Salix'. In: F.G. Meyer \& E.H. Walker (eds.). Flora of Japan. Smithsonian Institute, Washington, D.C., pp 362-369.

Leclercq, A. 1997. Wood quality of white willow. BASE: Biotechnology, Agronomy, Society and Environment 1: 59-64.

Metcalfe, G. 1939. Observations on the anatomy of the cricket-bat willow (Salix caerulea $\mathrm{Sm}$.). New Phytologist 38: 150-158.

Moura, V.P.G. 2002. Introdução de novas espécies de Salix (Salicaceae) no Planalto Sul de Santa Catarina, Brasil. Comunicado Técnico 71. Embrapa, Brasília, pp. 1-3.

Newsholme, C. 2002. Willows, the genus Salix. Timber Press, Portland.

Record, S.J. \& Hess, R.W. 1943. Timbers of the New World. Yale University Press, New Haven.

Richter, H.G. 1985. Wood and bark anatomy of Lauraceae II. Licaria Aublet. IAWA Bulletin n.s. 6: 187-199.

Schoch, W., Heller I., Schweingruber, F.H. \& Kienast, F. 2004. Wood anatomy of central european species online version: http://www.woodanatomy.ch (access in $28 / 07 / 2005$ ).

Sizonenko, O.Y. \& Chavchavadze, E.S. 2002. Wood anatomy in species of the genus Salix (Salicaceae) from northern regions of Russia. Botanisheskii Zhurnal 87: 67-77.

Tagliari, P.S. 1998. A cultura do vime em Santa Catarina: altos e baixos de uma alternativa econômica e social. Agropecuária Catarinense 11: 23-29. 